\title{
Change characteristics of DSi and nutrition structure at the Yangtze River Estuary after Three Gorges Project impounding and their ecological effect
}

\author{
Lei Li, Xinqiang Shen, Mei Jiang* \\ East China Sea Fisheries Research Institute Chinese Academy of Fishery Sciences, China \\ *Corresponding author's e-mail: jiangrose73@163.com
}

Keywords: Three Gorges Project, Yangtze River Estuary, DSi, nutrition structure.

\begin{abstract}
The variation law of dissolved silica (DSi), dissolved inorganic nitrogen (DIN), dissolved inorganic phosphorus (DIP) and nutrition structure after the Three Gorges Project (TGP) impounding as well as their ecological effect were analyzed according to monitoring survey of the Yangtze River Estuary in spring (May) and summer (August) from 2004-2009. The results showed that after impounding, DSi and DIN concentration decreased and increased, respectively. During the study period, DSi decreased by about $63 \%$, while DIN almost tripled. DIP concentration fluctuated slightly. With respect to nutrition structure, N:P increased, whereas Si:P and Si:N declined. According to chemometry standard of nutrient limits, nutrition structure tended to be imbalanced and the limiting factor of phytoplankton growth (P) was studied. Changes of nutrition structure have largely decreased diatom and caused different composition of dominant phytoplankton species. This may change ecosystem structure of the Yangtze River Estuary.
\end{abstract}

\section{Introduction}

DSi, one of important nutritive salts in hydrosphere, mainly comes from weathering of siliceous rocks in the nature and is carried away to the estuary and coastal waters with land runoffs. River is the main source of DSi in oceans, accounting for $82 \%$ (Treguer et al. 1995). Previous researches believed that DSi in rivers is mainly attributed to weathering, and it is slightly provided by human activities. It is often used as constant to correct changes of other nutrient elements (Carey and Fulweiler 2012). Different extent of reductions of DSi transportation to the ocean was observed after dam construction on the Danube (Humborg et al. 1997). This causes a series of ecological changes, such as reducing biological species in rivers and coastal regions, changing the population structure and deteriorating the primary productivity (Smetacek 1998).

China Yangtze Three Gorges Project (TGP), as one of the biggest hydropower-complex projects in the world, ranks as the key project for improvement and development of the Yangtze River. The dam is located in the areas of Xilingxia gorge, with an average annual runoff of 451 billion $\mathrm{m}^{3}$. The open valley at the dam site, with hard and complete granite as the bedrock, has provided the favorable topographical and geological conditions for the dam construction. On 8 Nov 1997, the river close-off succeeded, which indicates the construction target of the phase I was completed. On 6 Nov 2002, the close-off of the diversion channel succeeded. On 1st June 2003, the reservoir began its storage, the water reached $135 \mathrm{~m}$ on 10 June. The changes of water level of the
Three Gorges Reservoir will affect the distributional range of the brackish water in the Yangtze River estuary (Liu and Luo 1992). The construction of the TGP has influenced suspended matter concentration (Zhang et al. 2007). However, there were only some predictive researches dealing with effect of TGP on DSi before the construction and some short-term research after the Phase-I water storage (Yu et al. 2006). No long-term tracking monitoring study on the Yangtze River Estuary after the TGP construction has been reported yet.

Based on monitoring of the neighbor sea areas of the Yangtze River Estuary in Spring (May) and Summer (August) from 2004-2009, the long-term variation law, influencing factors and ecological effect of DSi after TGP impounding were analyzed, which provided references to long-term study of the effect of TGP on the ecosystem at the Yangtze River Estuary and the corresponding response.

\section{Materials and methods}

\section{Study area}

The Yangtze River, with a length of about $6300 \mathrm{~km}$, is the largest river in China and the third largest in the world. The Yangtze River Estuary of China is located at the junction of the East China Sea (ECS) and the Yellow Sea (YS), on the continental shelf at the western rim of the Pacific Ocean. The estuary and adjacent coastal waters are mainly affected by freshwater runoff from the Yangtze River. Runoff transportation in the Yangtze River is the main source of terrigenous materials in the East China Sea. 
The environment of the estuary is complicated and varied due to varied tides and the river bed landform. Like most of the estuaries in the world, the Yangtze River estuary is a very productive and resource-rich aquatic ecosystem (Ning et al. 2004). High primary production supports high fishery production of adjacent coastal water. The construction of the Three Gorges Dam has raised increasing concerns about the long-term changes of the Yangtze River and their impacts on the aquatic ecosystem in the estuary and adjacent coastal waters.

\section{Sample collection and analysis}

Sampling trips were conducted on a monthly basis from May and August of 2004 to 2009. Twenty stations were sampled on the Yangtze River Estuary (Fig. 1). A stainless steel reversing water sampler was used to collect the surface and bottom water samples at each station. Each sampling trip lasted four days, so each trip provided a 'snapshot' of the nutrient structure of the estuary at that time. The collected water samples were filtered by the pre-burned Whatman GF/F glass fiber membrane and fixed by $0.3 \%$ chloroform. Later, the samples were kept on ice in a dark cooler to inhibit biologic activity, and carried back to the laboratory for further analysis. The samples were defrosted for two days before DSi analysis to eliminate polymerization.

Ocean temperature (T), $\mathrm{pH}$ and salinity (Sal) were tested insite by using the YSI multi-parameter analyzer (YSI Company, USA). In the laboratory, the inorganic nutrients nitrate $\left(\mathrm{NO}_{3}\right)$, nitrite $\left(\mathrm{NO}_{2}\right)$, ammonium $\left(\mathrm{NH}_{4}\right)$, phosphate $\left(\mathrm{PO}_{4}\right)$, and silicate $\left(\mathrm{SiO}_{4}\right)$ were analyzed by flow injection using a SKALAR 5000 Automatic analyzer (SKALAR Company, Netherlands). Nitrite analysis was performed according to SKALAR 5000 Chemical Method. The term DIN in this paper is used to refer to the sum of all nitrogen species (i.e. $\mathrm{NO}_{3}+\mathrm{NO}_{2}+\mathrm{NH}_{4}$ ). $\mathrm{NO}_{3}$ concentration was tested by $\mathrm{Cd}-\mathrm{Cu}$ reduction method, $\mathrm{NO}_{2}$ concentration was tested by diazonium-azo method, and $\mathrm{NH}_{4}+-\mathrm{N}$ concentration was tested by ammonia-nitrogen approach. The terms DIP and $\mathrm{DSi}$ are used in this paper to refer to phosphate and silicate concentrations, respectively. Phosphate concentration was tested by molybdenum blue method. Silicate concentration was tested by silico moly plenum blue method. All samples were quantified against four working standards prepared from diluted stock standards to encompass the concentration ranges of the samples.

\section{Data processing}

Two-way ANOVA was used to test for temporal differences before and after nutrient loading reduction, as well as the spatial differences among sampling stations in various water quality and phytoplankton parameters. Tukey's test was used for multiple comparisons between sites. Kendall's correlation was used to test the correlation between phytoplankton and water quality variables.

\section{Results and discussion}

\section{Change characteristics of main environmental factors in the study sea area after water storage}

The inter-annual T in Spring and Summer from 2004-2009 ranges between $(17.50 \pm 1.27)-(28.17 \pm 1.32){ }^{\circ} \mathrm{C}$, showing an average value of $(23.65 \pm 4.11){ }^{\circ} \mathrm{C}$ and Spring $<$ Summer (Table 1). No significant difference has been observed $(p>0.05)$.

The inter-annual $\mathrm{pH}$ in Spring and Summer from 2004-2009 varies between $(7.80 \pm 0.20)-(8.41 \pm 0.05)$, with a mean of $(8.07 \pm 0.22)$ and Spring $>$ Summer (Table 1). There's no significant difference $(p>0.05)$.

The inter-annual Sal in Spring and Summer from 2004-2009 varies between $(17.79 \pm 7.16) \%$ - $(25.43 \pm 5.72) \%$, with a mean of $(20.51 \pm 7.56) \%$ and Spring $>$ Summer (Table $1)$. Significant difference was observed $(p<0.05)$.

$\mathrm{T}$ is mainly controlled by solar radiation. Meanwhile, the sea water temperature of the studying area is influenced significantly by land climate conditions because of its close geographical location to coastal regions. Different from continuous rising of sea water $\mathrm{T}$ (Boitsov et al. 2012), $\mathrm{T}$ of the study area fluctuated slightly within a short period (2004-2009), presenting no violent changes. The $\mathrm{pH}$ level

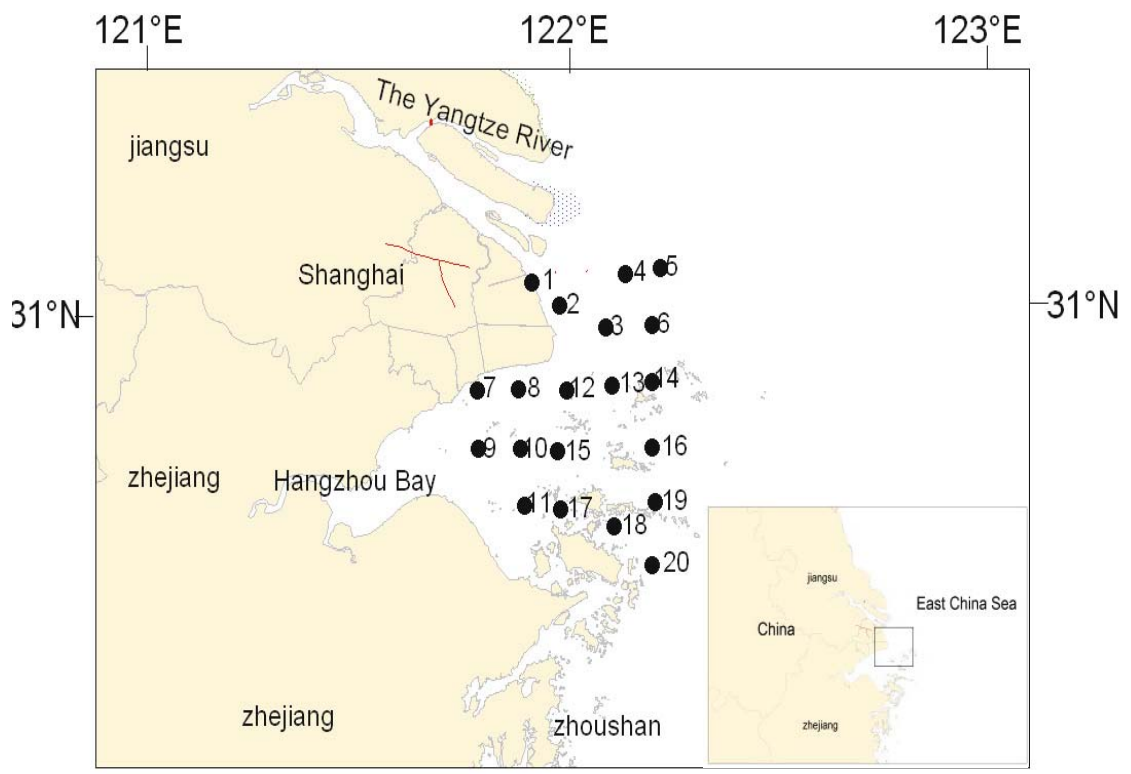

Fig. 1. Location of sampling stations 
Table 1. Changes of main environmental factors in the investigation area from 2004 to 2009

\begin{tabular}{ccccccccccccc}
\hline \multirow{2}{*}{$\begin{array}{c}\text { Main } \\
\text { environmental } \\
\text { factors }\end{array}$} & \multicolumn{2}{c}{2004} & \multicolumn{2}{c}{2005} & \multicolumn{2}{c}{2006} & \multicolumn{2}{c}{ Year } & 2007 & & 2008 & \\
\cline { 2 - 13 } & Spring & Summer & Spring & Summer & Spring & Summer & Spring & Summer & Spring & Summer & Spring & Summer \\
\hline $\mathrm{T}\left({ }^{\circ} \mathrm{C}\right)$ & $17.50 \pm 1.27$ & $28.15 \pm 0.67$ & $20.41 \pm 1.12$ & $26.23 \pm 0.49$ & $19.99 \pm 1.14$ & $25.99 \pm 1.58$ & $21.52 \pm 1.00$ & $27.96 \pm 1.91$ & $19.33 \pm 0.91$ & $28.03 \pm 1.66$ & $20.70 \pm 0.98$ & $28.17 \pm 1.32$ \\
$\mathrm{pH}$ & $7.80 \pm 0.20$ & $7.93 \pm 0.15$ & $7.90 \pm 0.15$ & $8.01 \pm 0.08$ & $8.23 \pm 0.15$ & $7.94 \pm 0.08$ & $8.41 \pm 0.05$ & $8.20 \pm 0.10$ & $8.13 \pm 0.13$ & $8.03 \pm 0.17$ & $8.18 \pm 0.17$ & $8.15 \pm 0.17$ \\
$\mathrm{Sal}(\% 0)$ & $25.43 \pm 5.72$ & $17.79 \pm 7.16$ & $18.00 \pm 7.59$ & $20.29 \pm 8.16$ & $23.86 \pm 6.00$ & $21.53 \pm 8.95$ & $19.17 \pm 7.85$ & $21.53 \pm 8.95$ & $19.69 \pm 7.68$ & $21.09 \pm 6.85$ & $21.49 \pm 6.20$ & $19.91 \pm 6.97$ \\
\hline
\end{tabular}

of sea water was controlled by dissociation equilibrium of carbonate system, generally ranging between 7.80-8.40. It was quite more stable compared to $\mathrm{pH}$ in other various natural water sources (Edmond et al. 1983). Significant difference in Sal in the surface and bottom waters in Spring and Summer is identified from 2004 to 2009. Spatial and temporal changes of Sal are mainly controlled by runoff amount, inlet split ratio, tide intensity and terrain conditions. Among them, runoff amount is the dominant cause of Sal change (Baodong 2006) and precipitation fluctuation is the most important cause of runoff amount changes (Cheng and Li 2002). The mean runoff amount of the Yangtze River (Datong Station) and mean Sal in Spring and Summer at the Yangtze River Estuary changed highly synchronously from 2004-2009 (Fig. 2). The linear regression equation is y $(\mathrm{Sal})=33.01-0.0005 \mathrm{x}$ (mean runoff amount), $\left(R^{2}=0.62, F=6.42, P=0.06\right)$. Generally, main environmental factors of the Yangtze River Estuary from 2004-2009 did not change greatly after water storage.

\section{Variation law of DSi, DIN and DIP after water storage}

After water storage, DSi concentration in the surface and bottom waters at the Yangtze River Estuary in Spring and Summer decreased continuously (Fig. 3a). It changed from $(21.10 \pm 8.85)-(38.64 \pm 14.08) \mu \mathrm{mol} \cdot \mathrm{L}^{-1}$ during the study period, showing a mean value of $(30.53 \pm 5.05) \mu \mathrm{mol} \cdot \mathrm{L}^{-1}$. Significant inter-annual difference was observed between the surface and bottom waters in both Spring and Summer $(p<0.05)$. The average annual DSi reduction in 2004-2009 was $2.23 \mu \mathrm{mol} \cdot \mathrm{L}^{-1}$. The average DSi concentration of 2009 was only $63.37 \%$ of that in 2004 .
Different from DSi concentration, DIN concentration in surface and bottom waters at the Yangtze River Estuary in Spring and Summer increased continuously after water storage. Such increase accelerated gradually (Fig. 3b). It varied between $(20.02 \pm 22.39)$ and $(88.31 \pm 28.95) \mu \mathrm{mol} \cdot \mathrm{L}^{-1}$, with a mean value of $(41.75 \pm 19.89) \mu \mathrm{mol} \cdot \mathrm{L}^{-1}$. There is a significant inter-annual difference between the surface and bottom waters in Spring $(p<0.05)$, but no significant difference in Summer $(P>0.05)$. The average DIN concentration of 2009 was 3.41 times higher than that in 2004.

DIP changed differently from DSi and DIN. It fluctuated slightly from 2004-2009 (Fig. 3c). DIP range of the surface and bottom waters in Spring and Summer from 2004-2009 was $(0.72 \pm 0.31)-(1.66 \pm 0.77) \mu \mathrm{mol} \cdot \mathrm{L}^{-1},(1.03 \pm 0.26) \mu \mathrm{mol} \cdot \mathrm{L}^{-1}$ on average. No significant inter-annual difference was observed between the surface and bottom waters in both Spring and Summer $(p>0.05)$.

Main environmental factors of the Yangtze River Estuary did not change greatly after water storage (Table 1), but DSi, DIN and DIP in the investigation area presented different variation trends (Fig. 3). Under natural conditions, DSi mainly comes from weathering of rocks in the drainage basin and is slightly influenced by human activities (Medeiros et al. 2011). DSi reduction may be related to large-scale damming behavior in the Yangtze River Basin. A series of complicated chain reactions will be triggered after damming in rivers, which will change the original physical, chemical and biological features of rivers. Associated research pointed out that sediment runoff in 1year after the Phase-I waters storage was reduced by $28 \%$. The reservoir formed by damming and water storage has

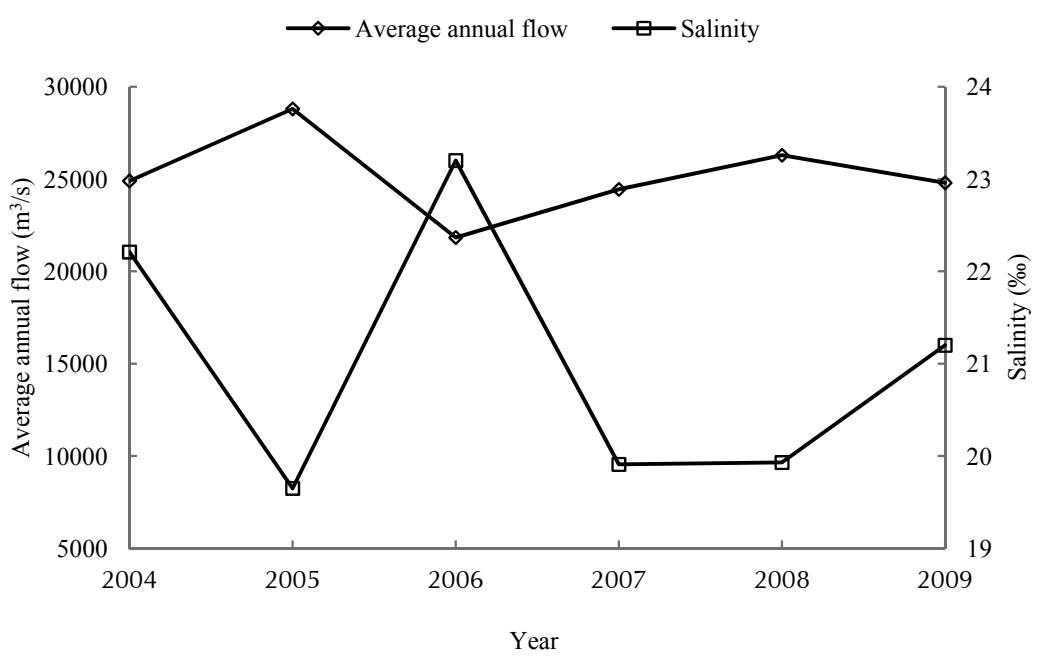

Fig. 2. Annual average of runoff amount and salinity in the Yangtze River Estuary from 2004 to 2009 
different retaining capacities of different nutritive salts and has high retained capacity of Si (Friedl and Wüest 2002). Since the 'man-made lake' effect will reduce sediments and increase light transmittance, it is easier for diatom to grow, increasing diatom bloom frequency. Meanwhile, diatom submerged more quickly than other algae. Compared to $\mathrm{N}$ and $\mathrm{P}$, biological silica (BSi) is more difficult to be decomposed and has longer regeneration period, resulting in abundant Si deposited in the reservoir and less DSi flux to the ocean (Conley et al. 1993). This agrees with reports that DSi concentration decreases in coastal water after damming construction (Humborg et al. 1997). DSi reduction of the Yangtze River Estuary existed before the water storage. DSi flux from the Yangtze River to the ocean has been jumping down since 1968 when the Danjiangkou Dam was constructed (Li and Chen 2001). In this paper, DSi concentration decreased by $2.23 \mu \mathrm{mol} \cdot \mathrm{L}^{-1}$ every year from 2004-2009, indicating that the TGP construction further intensified DSi reduction. However, such DSi reduction is far more smaller than that in the Danube caused by the "Iron Gate" Dam (accounting for $80 \%$ of the total DSi flux reduction of the Black Sea - it decreased by 15 million tons from 1975-1990) and that in the Nile downstream $\left(200 \mu \mathrm{mol} \cdot \mathrm{L}^{-1}\right)$ caused by the Aswan Dam construction. Considering the simple source of DSi, the DSi supplement to downstream river basins of the TGP may be the little reason for such smaller DSi reduction.

The 'man-made lakes' formed by damming also will reduce DIN and DIP outlets (Tarkowska-Kukuryk 2013). Nevertheless, DIN and DIP concentrations changed differently from DSi after water storage. No evident reduction of DIN and DIP was seen. This is because DIN concentration changes of the Yangtze River Estuary are mainly controlled by $\mathrm{N}$ inlet which increases year by year (Zhang et al. 1998). Most $\mathrm{N}$ outlets of various forms of the investigation area are contributed by middle streams and downstream of the TGP. Annual increase from agricultural fertilization and domestic wastewater drainage in the Yangtze River Basin as well as atmosphere $\mathrm{N}$ deposition are the main reason of $\mathrm{N}$ increase in Yangtze waters ( $\mathrm{Gu}$ et al. 2015). This conforms to the sharp increase in $\mathrm{N}$ flux to the ocean around the whole world. $\mathrm{N}$ circle has been changed greatly from the worldwide production of nitrogen-fixing plants, fertilizer production and usage, changes from habitat for animals and plants as well as combustion of fossil fuel. All of these factors make inland $\mathrm{N}$ outlet doubled in the past five decades. Such $\mathrm{N}$ outlet increase is still continuing (Vitousek et al. 1997). As a result, $\mathrm{N}$ outlets contributed by middle streams and downstream of the TGP not only supplement $\mathrm{N}$ retention caused by 'man-made lakes', but also increase DIN concentration of the investigation area continuously after water storage(Kostecki and Suschka 2013). DIP concentration of the investigation area remained basically the same in the 6 studying years. It only fluctuated slightly. This may be related to the constant phosphate concentration of the fresh water of the Yangtze River Estuary (Li et al. 2011) and buffer mechanisms of phosphate at the estuary (Froelich 1988). The buffer mechanisms of phosphate at the estuary are mainly controlled by particle-water interaction. Due to the high adsorption capacity of the suspended solids at the estuary, water areas at the estuary with high content of suspended particles could adsorb abundant phosphates, whereas phosphates adsorbed in water areas with few suspended particles are released into waters again. This explains the small change of phosphate concentration of the whole Yangtze River Estuary.
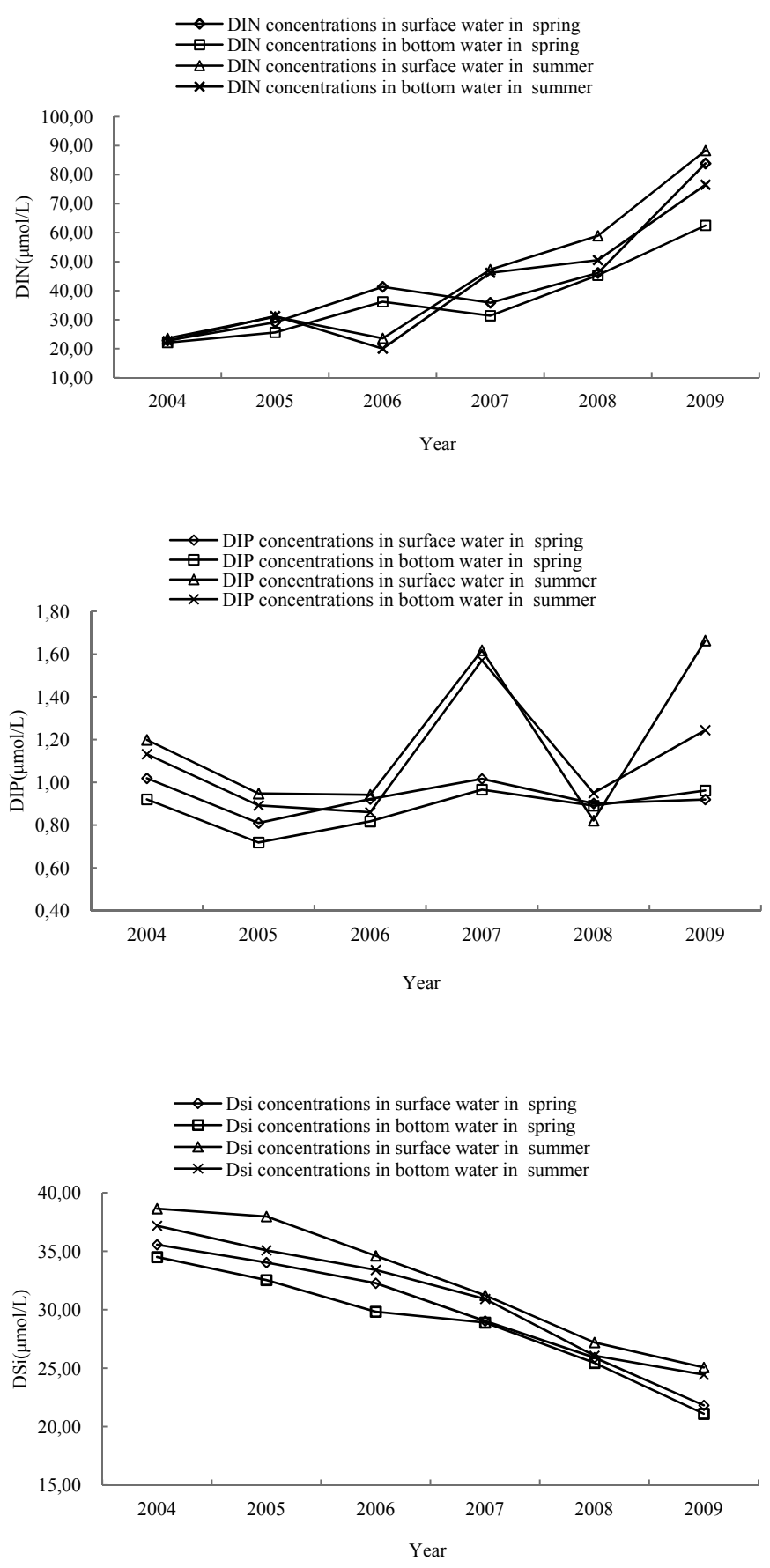

Fig. 3. Concentrations of DSi, DIN and DIP in the investigation area after water storage

Nutrition structure change characteristics after water storage in the investigation area and its effect

Nutrition concentration change is surely accompanied by change of nutrition structure. After the water storage, N:P at the Yangtze River Estuary from 2004-2009 increased, while Si:P and Si:N decreased (Table 2). N:P in surface and bottom waters in Spring and Summer ranged between 10.51-57.34, 22.67 on average. N:P in 2009 was 3.28 times higher than that in 2004. Si:P in surface and bottom waters in Spring and Summer changed between 19.81-46.12, 33.36 on average. Si:P in 2009 was $39.39 \%$ lower than that in 2004 . Si:N range in surface and bottom waters in Spring and Summer was $0.52-3.34,1.86$ on average. Si:N in 2009 was $81.22 \%$ lower than that in 2004. 
Table 2. Ratios of nutrients in the surface and bottom waters and spring and summer in the investigation area

\begin{tabular}{|c|c|c|c|c|c|c|c|c|c|c|c|c|}
\hline \multirow{3}{*}{ Item } & \multicolumn{6}{|c|}{ Surface water } & \multicolumn{6}{|c|}{ Bottom water } \\
\hline & \multicolumn{2}{|c|}{$\mathrm{Si} / \mathrm{P}$} & \multicolumn{2}{|c|}{$\mathrm{Si} / \mathrm{N}$} & \multicolumn{2}{|c|}{$\mathrm{N} / \mathrm{P}$} & \multicolumn{2}{|c|}{$\mathrm{Si} / \mathrm{P}$} & \multicolumn{2}{|c|}{$\mathrm{Si} / \mathrm{N}$} & \multicolumn{2}{|c|}{$N / P$} \\
\hline & Spring & Summer & Spring & Summer & Spring & Summer & Spring & Summer & Spring & Summer & Spring & Summer \\
\hline 2004 & 46.12 & 39.83 & 3.11 & 3.28 & 14.82 & 12.15 & 33.86 & 41.48 & 3.12 & 3.28 & 10.85 & 12.63 \\
\hline 2005 & 37.94 & 36.18 & 2.34 & 2.45 & 16.21 & 14.78 & 40.88 & 35.51 & 2.54 & 2.24 & 16.09 & 15.83 \\
\hline 2006 & 31.61 & 33.18 & 1.56 & 2.93 & 20.24 & 11.31 & 32.96 & 35.07 & 1.65 & 3.34 & 19.99 & 10.51 \\
\hline 2007 & 37.79 & 43.40 & 1.62 & 1.32 & 23.34 & 32.86 & 40.57 & 30.17 & 1.84 & 1.34 & 22.02 & 22.53 \\
\hline 2008 & 25.95 & 29.91 & 1.12 & 0.92 & 23.10 & 32.40 & 25.80 & 24.78 & 1.12 & 1.03 & 22.97 & 24.03 \\
\hline 2009 & 21.43 & 32.56 & 0.52 & 0.57 & 41.17 & 57.34 & 19.81 & 23.95 & 0.68 & 0.64 & 29.35 & 37.50 \\
\hline Mean & 33.47 & 35.84 & 1.71 & 1.91 & 23.15 & 26.81 & 32.31 & 31.83 & 1.83 & 1.98 & 20.21 & 20.50 \\
\hline
\end{tabular}

$\mathrm{N}: \mathrm{P}, \mathrm{Si}: \mathrm{P}$ and Si:N could reflect nutrition state of sea water clearly. The atomic ratio of $\mathrm{Si}: \mathrm{N}: \mathrm{P}$ is $16: 16: 1$ (Redfield et al. 1963). It varies from different sea areas due to different physical, biological and chemical influencing factors. Appropriate N:P, Si:P and $\mathrm{Si}: \mathrm{N}$ are in favor of phytoplankton growth and reproduction. On the contrary, lack of one nutrient element will inhibit biological growth and reproduction. Excessive content of one element or imbalanced nutrition structure will affect plankton population structure significantly and even will cause red tide (Sellner et al. 2003). At the Yangtze River Estuary, nutrition proportions and some physical conditions may be more important to eutrophication control compared to single nutrition load with concentration (Sharp 2003).

Molar ratios of nutrients in the Yangtze River Estuary from 2004 to 2009 after water storage are listed in Table 2. Nutrient ratios of the investigation area have become imbalanced to a certain extent. According to stoichiometric molar ratios of nutrients, phytoplankton growth is inhibited by $\mathrm{P}$ when $\mathrm{Si} / \mathrm{P}$ $>22$ and $\mathrm{N} / \mathrm{P}>22$; it is inhibited by $\mathrm{N}$ when $\mathrm{N} / \mathrm{P}<10$ and $\mathrm{Si} / \mathrm{N}$ $>1$; and $\mathrm{Si}$ when $\mathrm{Si} / \mathrm{P}<10$ and $\mathrm{Si} / \mathrm{N}<1$ (Justic et al. 1995). The judgment based on this standard demonstrated that $\mathrm{P}$ is still the inhibiting factor of phytoplankton at the Yangtze River Estuary after water storage. It is important to note that although the nutrition structure changes did not cause Si inhibition in this sea area, the main environmental factors after water storage remained basically the same in the 6 studying years (Table 1). However, Rantajärvi et al. reported that low DSi supply will inhibit the increase of diatom biomass or growth rate, with the reduction of diatom biomass (Rantajärvi et al. 1997). Phytoplankton communities in the Yangtze River Estuary began to change from diatom communities into dinoflagellates communities. Meanwhile, the 559 red tides that occurred in the whole Chinese sea areas, including the Yangtze River Estuary and the East Sea in the $20^{\text {th }}$ century, reflected that the occurrence rate of red tide increases year by year, especially after the 1980s (Cheng and Li 2002). However, the occurrence rate of diatom red tides in nearshore decreased, accompanied by conversion from large red tide organisms (more diatom species) to small and tiny organisms (more dinoflagellates species) (Jeong et al. 2013). Such conversion has been witnessed in the Gulf of Mexico (Turner and Rabalais 19991). Nutrition concentration and structure changes may be the main causes of phytoplnkton quantity and composition changes. On the one hand, the reduction of large diatom and changes of dominant phytoplankton species will increase occurrence rate of toxic non-algae red tide and give birth to non-bait ecological groups of phytoplankton, thus influencing food structure of zooplankton and other marine animals that live mainly with diatom. On the other hand, a long-term effect may even decrease fish resources and diversity. The effect of nutrition concentration and structure changes of the Yangtze River Estuary caused by the river damming except for fishing intensity on the biogeochemistry circulation and coastal ecological structure deserves further deep studies.

\section{Conclusions}

After impounding, DSi and DIN concentration decreased and increased, respectively. With respect to nutrition structure, N:P increased, whereas Si:P and Si:N declined. According to chemometry standard of nutrient limits, nutrition structure tended to be imbalanced and the limiting factor of phytoplankton growth $(\mathrm{P})$ was studied. Changes of nutrition structure have largely decreased diatom and caused different composition of dominant phytoplankton species. This may change the ecosystem structure of the Yangtze River Estuary.

\section{Acknowledgments}

This work was supported by China Ministry of Science and Technology under Contract (G2010CB429005).

\section{References}

Baodong, W. (2006). Culturaleutrophication in the Changjiang (Yangtze River) plume, History and perspective, 69, pp. 471-477.

Boitsov, V.D., Karsakov, A.L. \& Trofimov, A.G. (2012). Atlantic water temperature 259 and climate in the Barents Sea, 2000-2009, Ices Journal of Marine Science, 69, pp. 833-840.

Carey, J.C. \& Fulweiler, R.W. (2012). Human activities directly alter watershed dissolved silica fluxes, Biogeochemistry, 111, pp. $125-138$.

Cheng, H.Q. \& Li, M.T. (2002). Dissolved silicate flux fluctuation from river into the sea: a case study in Changjiang, Resources and Environment in the Yangtze Basin, 10(6), pp. 558-563. (in Chinese)

Conley, D.J., Chelske, C.L. \& Stoermer, E.F. (1993). Modification of the biogeochemical cycle of silica with eutrophication, Marine Ecology Progress Series, 101, pp. 179-192. 
Edmond, J.M., Spivack, A., Grant, B.C., Hu, M.-H., Chen, Z., Chen, S. \& Zeng, X. (1983). Chemical dynamics of the estuary of the Changjiang River, Proceeding of international symposium on sedimentation on the continental shelf with special reference to the East China Sea, 1, pp.251-262.

Friedl, G. \& Wüest, A. (2002). Disrupting biogeochemical cycles consequences of damming, Aquatic Sciences-Research across boundaries, 64, pp. 55-65.

Froelich, P.N. (1988). Kinetic control of dissolved phosphate in natural rivers and estuaries: a primer on the phosphate buffer mechanism, Limnology and Oceanography, 33, pp. 649-668.

Gu, H., Yu, Z., Wang, G., Wang, J., Ju, Q., Yang, C. \& Fan, C. (2015). Impact of climate change on hydrological extremes in the Yangtze River Basin, China, Stochastic Environmental Research \& Risk Assessment, 29, pp. 693-707.

Humborg, C., Ittekkot, V., Cociasu, A. \& Bodungen, B.V. (1997). Effect of Danube River dam on Black Sea biogeochemistry and ecosystem structure, Nature, 386, pp. 385-388.

Jeong, H.J., Yoo, Y.D., Lee, K.H., Kim, T.H., Seong, K.A., Kang, N.S., Lee, S.Y., Kim, J.S., Kim, S. \& Yih, W.H. (2013). Red tides in Masan Bay, Korea in 2004-2005: I. daily variations in the abundance of red-tide organisms and environmental factors, Harmful Algae, 30, pp. 75-88.

Justic, D., Rabalais, N.N., Turner, R.E. \& Dortch, Q. (1995). Changes in nutrient structure of river-dominated coastal waters: stoichiometric nutrient balance and its consequences, Estuarine, Coastal and Shelf Science, 40(3), pp. 339-356.

Kostecki, M. \& Suschka, J. (2013). The successful results of Plawniowice reservoir (upper Silesia region-south of poland) restoration by hypolimnetic withdrawal, Archives of Environmental Protection, 39, pp. 17-25.

Li, M.T. \& Chen, H.Q. (2001). Changes of dissolved silicate flux from the Changiiang River into sea and its influence since late 50 years, China Environmental Science, 21, pp. 193-197. (in Chinese)

Li, X., Yang, L. \& Yan, W. (2011). Model analysis of dissolved inorganic phosphorus exports from the Yangtze River to the estuary, Nutrient Cycling in Agroecosystems, 90, pp. 157-170.

Liu, R.Y. \& Luo, B.Z. (1992). Impacts of the three gorges project on the ecology and environment of the Changjiang river estuary and adjacent waters, Studia Marina Sinica, 33,pp. 1-13. (in Chinese)

Medeiros, P.R.P., Knoppers, B.A., \& Cavalcante, G.H. (2011). Changes in nutrient loads (N, P and $\mathrm{Si}$ ) in the São Francisco estuary after the construction of dams, Brazilian Archives of Biology \& Technology, 54, pp. 387-397.
Ning, X.R., Shi, J.X., Cai, Y.M. \& Liu, C. (2004). Biological productivity front in the Changjiang Estuary and the Hangzhou Bay and its ecological effects, Acta Oceanologica Sinica, 26, pp. 96-106. (in Chinese)

Rantajärvi, E., Gran, V., Hällfors, S. \& Olsonen, R. (1997). Effects of environmental factors on the phytoplankton community in the Gulf of Finland-unattended high frequency measurements and multivariate analyses, Hydrobiologia, 363, pp. 127-139.

Redfield, A.C., Ketchum, B.H. \& Richards, F.A. (1963). The influence 296 of organisms on the composition of seawater, New York: John Wiley, Sea, pp. 26-77.

Sellner, K.G., Doucette, G.J. \& Kirkpatrick, G.J. (2003). Harmful algal blooms: causes, impacts and detection. Journal of Industrial Microbiology \& Biotechnology, 30, pp. 383-406.

Sharp, J.H. (2003). Long term nutrient trends and phytoplankton response in Delaware Estuary. USA. Dallas: Crown Press.

Smetacek, V. (1998). Biological oceanography: Diatoms and the silicate factor, Nature, 391, pp. 224-225.

Tarkowska-Kukuryk, M. (2013). Effect of phosphorous loadings on macrophytes structure and trophic state of dam reservoir on a small lowland river (Eastern Poland), Archives of Environmental Protection, 39, pp. 33-46.

Treguer, P., Nelson, D.M., Van Bennekom, A.J., DeMaster, D.J., Leynaert, A. \& Quéguine, B.(1995). The silica balance in the world ocean: a reestimate, Science, 268,pp. 375-379.

Turner, R.E. \& Rabalais, N.N. (1991). Changes in Mississippi River water quality this century: implications for coastal food webs, Bioscience, 41, pp. 140-147.

Vitousek, P.M., Aber, J.D., Howarth, R.W., Likens, G.E., Matson, P.A., Schindler, D.W., Schlesinger, W.H. \& Tilman, D.G. (1997). Human alteration of the global nitrogen cycle: sources and consequences, Ecological applications, 7, pp. 737-750.

Yu, L.H., Li, D.J., Fang, T., Li, Y. \& Gao, L. (2006). Distributions of DSi, DIN and changes of Si: $\mathrm{N}$ ratio on summer in Changjiang estuary before and after storage of Three Gorges Reservoir, Acta Ecologica Sinica, 26, pp. 2817-2826. (in Chinese)

Zhang, C., Wang, L., Zhang, S. \& Li, X. (1998). Geochemistry of rare earth elements in the mainstream of the Yangtze River, China, Applied Geochemistry, 13, pp. 451-462.

Zhang, J., Wu, Y., Jennerjahn, T.C., Ittekkot, V. \& He, Q. (2007). Distribution of organic matter in the Changjiang (Yangtze River) Estuary and their stable carbon and nitrogen isotopic ratios: Implications for source discrimination and sedimentary dynamics, Marine Chemistry, 106, pp. 111-126. 